\title{
Theory of 25-year-cycle evolution - a hypothesis about the relationship between the transition of economic development mode and the human resource management innovation
}

\author{
Lin Xinqi \\ Department of Human Resource Management School of Labor and Human \\ Resources, Renmin University of China, Beijing,100872, P.R.China
}

\begin{abstract}
Based on systematic researches on the relationship between the transition of economic development mode and the human resource management innovation in China, Japan and USA during a long period, that is a century, this paper found a periodic feature: with the transition of economic development mode, there is one climax after another of human resource management innovation. The cycle probably evolved once every 25 years or so. In such an interactive process, transition of economic development mode calls for the human resource management innovation, and vice-versa. Especially, the human resource management innovation presents increasingly dominant role. Although this can merely be deemed as a hypothesis in a strict sense, it offers a great deal of implications from the perspective of reference to observe and analyze lots of economic and management phenomena and to look forward to problems related to future development of macro management of enterprises.
\end{abstract}

Key words: Changes, Economic development, HRM innovation, Evolution, China, Japan and USA

\section{INTRODUCTION}

In the year of 1911, which was exactly 100 years ago, symbolized by the publication of Scientific Management of Taylor, modern Management Science was born. In the past century, on the basis of Scientific Management, modern management science gradually enriched and developed affecting practices in a more important manner. Meanwhile, much exploration has been made regarding the relationship between management theories and management practices, as well as their development features and rules. Lots of thought-provoking ideas were put forwarded reflecting and referencing by either researchers or practitioners. In 1939, by integrating opinions of his predecessors, the well-known American Austrian economist Joseph Alois Schumpeter created the "theory of innovation" amd firstly proposed Tri-cycle three cycles, i.e. short, middle and long term cycles - during the course of economic development. Theory coexisted in the capitalist economy. "Long cycle" (long wave) refers to "Kondratiev cycle", "mid cycle" (middle wave) refers to "Juglar cycle", "short cycle" (short wave) implies "Kitchin Cycle". Schumpeter claimed that these three cycles co-existed and interrelated to each other and further proved the appropriateness of his innovation theory. In his opinion, a long cycle includes six middle cycles, where a middle cycle comprises three short cycles. Schumpeter took over the ideas of Kondratiev, divided the process of capitalist economy of the past century into three long waves and took it as the basis of innovation theory symbolized by major technological inventions and applications, along with the outstanding development of production technology for each long wave. As for the periodic economic fluctuation, Schumpeter explained by innovations, which implies both technological and organizational, institutional innovations. In his book "Theory of Economic Development" published in 1934, Schumpeter divided the three long cycles as follows: The first long wave lasted from 1780s to 1850 s, which is called the first industrial revolution period. The characteristic of this period is from manual production or steamers made in factories to all industrial sectors and countries. The second long wave lasted from 1850s to the end of 1800 , i.e. so-called steamer and steel era or railway era, which is characterized by steamer produced by machines as source of power and was widely spread. The third long wave started from 1898 (while the second long waves had not yet come to an end, i.e.) as electric, chemical and automobile era featured with a wide use of electric motors and engine in industrial sectors. In 1992, American management researcher Steven Barley and Robert Kunda found that for more than a century, management thoughts as rationalism (scientific management) and irrationalism (humanism) alternately dominated the management academia every 20 to 30 years. Steven Barley and Robert Kunda also found that alternations of management thoughts were closely related to the macro economy. That is to say, on one hand, the rationalism took advantage when the economy boomed, on the other hand, as the economy stagnated, humanism gained the upper hand. For example, the Great Depression in 1929 helped Human Relationship took the wind. Nevertheless, the economic takeoff after the World War enabled rationalism to take advantage. The rise of Japan in 1880s ushered another campaign of corporate culture. Steven Barley and Robert Kunda offered such an explanation, i.e. rationalism won as the corporate performance was seemingly closely related to effective management of capitals. However, humanism won when the corporate performance was 


\section{Lin Xinqi}

Theory of 25-year-cycle evolution - a hypothesis about the relationship between the transition of economic development mode and the human resource management innovation

seemingly closely related to effective management of labors. The 1994-2000 periods enjoys one of the best economies, with high growth, high employment, and low inflation. In accordance with the above said principle, rationalism is supposed to dominate. Not surprisingly, the most popular corporate theories are either resource based or knowledge based. Learning Organization and the Fifth Discipline are most popular in the practical field, as well as such book as A Message to Garcia, all sorts of information management systems, including ERP, the aim of which is to take rational controls in a maximum way by reengineering the procedures with newest information technologies.Ever since 1990s, the rapid development based on information technologies pushed the insight changes on economic operation mechanism, meso economic structure and model of macroeconomic management. Under the circumstances of more knowledge of element investment, more information processing applications on the Internet, more innovation in competition, more flexibility in manufacturing and globalization in operation, economic cycle in USA is gradually showing new trend.Up to now, researches on economic development and management cycle are fundamentally based on discussions of economy and investment, and more in circles in sort of deterministic way. On the contrary, based on the historic investigations of the relationship between economic development and management innovation in Japan, China and USA, particularly the systematic researches on the model changes of economic development and HRM innovation, the author found an important and regular phenomenon, i.e. a 25-year-evolution rule.

\section{THE “25-YEAR-EVOLUTION" - USA, JAPAN AND CHINA}

Table 1: USA - Model Changes of Economic Development and Management Innovation (1911-2011)

\begin{tabular}{|c|c|c|c|}
\hline Years & 1911- & 1936- & 1961- \\
\hline $\begin{array}{l}\text { Model Changes } \\
\text { of Economic } \\
\text { Development }\end{array}$ & $\begin{array}{l}\text { Development of general } \\
\text { industries: collaboration } \\
\text { between machine } \\
\text { production } \\
\text { labor-intensive industries }\end{array}$ & $\begin{array}{lr}\text { Growing of } & \text { heavy } \\
\text { industry: } & \text { further } \\
\text { development } & \text { on } \\
\text { industrialization } & \text { and } \\
\text { collaboration } & \end{array}$ & $\begin{array}{l}\text { Rapid development of } \\
\text { trans-national companies and } \\
\text { international trade: increasing } \\
\text { of added value, brand } \\
\text { protection and global industrial } \\
\text { chain management }\end{array}$ \\
\hline $\begin{array}{l}\text { Management } \\
\text { Innovation }\end{array}$ & $\begin{array}{l}\text { Tayloristic scientific } \\
\text { management: } \\
\text { management innovation } \\
\text { aimed at improving unit } \\
\text { productivity }\end{array}$ & $\begin{array}{l}\text { Production management } \\
\text { on the assembly line, } \\
\text { people-oriented HRM } \\
\text { innovation }\end{array}$ & $\begin{array}{l}\text { comparative management, cross } \\
\text { cultural management, } \\
\text { international HRM: } \\
\text { trans-national } \\
\text { management innovation }\end{array}$ \\
\hline Years & 1986- & 2011- & \\
\hline $\begin{array}{l}\text { Model Changes } \\
\text { of Economic } \\
\text { Development }\end{array}$ & $\begin{array}{l}\text { Large scale overseas } \\
\text { moving of development of } \\
\text { manufacturing industry, } \\
\text { technology standard, } \\
\text { technology leading and } \\
\text { knowledge economy }\end{array}$ & $\begin{array}{l}\text { Co-development and } \\
\text { balance between } \\
\text { high-end manufacturing } \\
\text { industry and modern } \\
\text { service industry, and } \\
\text { restructuring of global } \\
\text { industry distribution }\end{array}$ & \\
\hline $\begin{array}{l}\text { Management } \\
\text { Innovation }\end{array}$ & $\begin{array}{l}\text { Manufacturing and service } \\
\text { out-sourcing } \\
\text { management } \\
\text { management of learning } \\
\text { organization, } \\
\text { management innovation } \\
\text { on emphasis on core } \\
\text { competency and balance } \\
\text { development }\end{array}$ & $\begin{array}{l}\text { Development of } \\
\text { knowledge based HRM, } \\
\text { further development on } \\
\text { differentiation, } \\
\text { diversification and cross } \\
\text { culture management }\end{array}$ & \\
\hline
\end{tabular}

Source: compilation by the author

The "25-year-evolution" thought is from such perspectives as management, model changes of economic development, the relationship between economic development and management innovation, as well as upgrading, evolution and development, instead of moving in turns. Each cycle did push the model changes of economic development, improved management innovation, HRM innovation in particular. Having 


\section{Lin Xinqi}

Theory of 25-year-cycle evolution - a hypothesis about the relationship between the transition of economic development mode and the human resource management innovation

investigated the whole process of corporate management and HRM in USA and Europe, we can easily find out this regular feather. That is to say, with the model changes of economic development, tide after tide of management innovation appeared. Cases in Japanese companies after the second World War proved the same regularity, the cycle of which is roughly 25 years. Details can be found in the table below.

Table 2: Japan - Model Changes of Economic Development and Management Innovation (1945-2045)

\begin{tabular}{|c|c|c|c|}
\hline Years & 1945- & 1970- & 1995- \\
\hline $\begin{array}{l}\text { Model Changes } \\
\text { of Economic } \\
\text { Development }\end{array}$ & $\begin{array}{l}\text { Development and } \\
\text { upgrading of } \\
\text { export-oriented and labor } \\
\text { intensive industry, rising } \\
\text { of modern industry }\end{array}$ & $\begin{array}{l}\text { Growing of heavy } \\
\text { industry, development } \\
\text { of urbanization and } \\
\text { development of } \\
\text { trans-national } \\
\text { businesses }\end{array}$ & $\begin{array}{l}\text { Rapid development } \\
\text { of real estate, } \\
\text { banking service, as } \\
\text { well as stagnation } \\
\text { and adjustment } \\
\text { after burst of } \\
\text { economic bubbles }\end{array}$ \\
\hline $\begin{array}{l}\text { Management } \\
\text { Innovation }\end{array}$ & $\begin{array}{l}\text { Migration of labors from } \\
\text { rural to urban areas, } \\
\text { intensive management } \\
\text { of labors disputes and } \\
\text { mediation }\end{array}$ & $\begin{array}{l}\text { Formation and } \\
\text { enhancing of life-time } \\
\text { employment, senior } \\
\text { system, enterprise } \\
\text { union as well as } \\
\text { realization of double } \\
\text { pay plan }\end{array}$ & $\begin{array}{l}\text { Introduction of } \\
\text { competition } \\
\text { mechanism and } \\
\text { meritocracy } \\
\text { management, HRM } \\
\text { innovation of } \\
\text { internationalization } \\
\text { of transnational } \\
\text { companies, } \\
\text { avocations of } \\
\text { knowledge -based } \\
\text { management }\end{array}$ \\
\hline Years & 2020- & 2045- & \\
\hline $\begin{array}{l}\text { Model Changes } \\
\text { of Economic } \\
\text { Development }\end{array}$ & $\begin{array}{l}\text { Economic revitalization, } \\
\text { balance and } \\
\text { co-development of } \\
\text { high-end manufacturing } \\
\text { and modern service } \\
\text { industries, } \\
\text { re-distribution and } \\
\text { adjustment of global } \\
\text { industrial division }\end{array}$ & $\begin{array}{l}\text { Maintaining the } \\
\text { position of economic } \\
\text { big power, the } \\
\text { leading position } \\
\text { technology-wise in the } \\
\text { international industrial } \\
\text { layout, adapting to } \\
\text { economy of more } \\
\text { aged and less children }\end{array}$ & \\
\hline $\begin{array}{l}\text { Management } \\
\text { Innovation }\end{array}$ & $\begin{array}{l}\text { Development of } \\
\text { knowledge based HRM } \\
\text { further development on } \\
\text { differentiation, } \\
\text { diversification and cross } \\
\text { culture management }\end{array}$ & $\begin{array}{l}\text { Adapting to the HRM } \\
\text { innovation under the } \\
\text { circumstances of } \\
\text { internationalization, } \\
\text { informationalization, } \\
\text { more aged and less } \\
\text { children }\end{array}$ & \\
\hline
\end{tabular}

Source: compilation by the author

We can tell that model changes of economic development call for management innovation, particularly management innovation, and HRM innovation promotes model changes of economic development. In the interactive process, management innovation or HRM innovation is playing a more and more leading part. Thus, examining the experiences of enterprises development, the successful enterprises always keep up with HRM innovation, instead of waiting or adapting passively. This is not only true to a company, but also a region and a whole nation. To meet the requirement of different economic development stages, management innovation, especially HRM innovation should focus differently. For example, at the early stage of economic development focus should be on efficiency and regulation. Therefore, the focus of innovation should be on management technology and mechanism. Whereas at the middle stage, when attention is paid to sustainable development, focus should be made on fairness on the basis of efficiency as for HRM innovation, and building scientific and feasible HRM model and such fundamental systems as decent employment, incentive pay for performance and stable labor relations 
Lin Xinqi

Theory of 25-year-cycle evolution - a hypothesis about the relationship between the transition of economic development mode and the human resource management innovation

\section{Table 3: China - Model Changes of Economic Development and Management Innovation (1949-2049)}

\begin{tabular}{|c|c|c|c|}
\hline Years & 1949- & 1974- & 1999- \\
\hline $\begin{array}{l}\text { Model Changes of } \\
\text { Economic } \\
\text { Development }\end{array}$ & $\begin{array}{l}\text { National liberation, from } \\
\text { war to peace; planned } \\
\text { economy, the Soviet } \\
\text { Union Model, priority } \\
\text { given to the development } \\
\text { of heavy industry }\end{array}$ & $\begin{array}{l}\text { Proposing the goals of Four } \\
\text { Modernizations, Deng } \\
\text { Xiaoping returned to the } \\
\text { government; introduction of } \\
\text { commercial economy, } \\
\text { realizing opening up and } \\
\text { reform. Development of } \\
\text { export orientation, labor } \\
\text { intensive industries. }\end{array}$ & $\begin{array}{l}\text { Reform in the state-owned } \\
\text { enterprises, share-holding } \\
\text { system, economic } \\
\text { globalization, entry into the } \\
\text { WTO, upgrading of } \\
\text { industries and development } \\
\text { of modern service industry, } \\
\text { banking, real estate, from } \\
\text { export orientation to the } \\
\text { expansion of domestic } \\
\text { demand. }\end{array}$ \\
\hline $\begin{array}{l}\text { Management } \\
\text { Innovation }\end{array}$ & $\begin{array}{l}\text { Low pay, } \begin{array}{r}\text { high } \\
\text { rate, }\end{array} \\
\text { employment } \\
\text { centralized distribution, } \\
\text { jobs and allocation with } \\
\text { low flow, high stability, } \\
\text { paternalism, } \\
\text { centralization, } \\
\text { equalitarianism, and } \\
\text { public ownership }\end{array}$ & $\begin{array}{l}\text { Break up the "communal } \\
\text { pot", "iron rice bowl" and } \\
\text { life-time employment , } \\
\text { limited market competition } \\
\text { mechanism, widen the } \\
\text { income gaps, "being rich first } \\
\text { being proud" mentality }\end{array}$ & \begin{tabular}{lr} 
Optimization & \multicolumn{2}{c}{ grouping, } \\
laid-off, job bidding , \\
welfare monetization, \\
performance \\
development of labor, \\
disputes and mediation \\
exploration, achieving \\
management innovation of \\
results sharing and double \\
growth, and concerning \\
about sustainability
\end{tabular} \\
\hline Years & 2024- & 2049- & \\
\hline $\begin{array}{l}\text { Model Changes of } \\
\text { Economic } \\
\text { Development }\end{array}$ & $\begin{array}{l}\text { Scientific development, } \\
\text { all-round well-off, } \\
\text { achieving the national } \\
\text { development goals of } \\
\text { 2020. Rapid development } \\
\text { of modern manufacturing } \\
\text { and service industries, as } \\
\text { well as transnational } \\
\text { businesses and } \\
\text { corporate, industry } \\
\text { restructuring and } \\
\text { upgrading, formation of } \\
\text { modern enterprise } \\
\text { systems, realization of } \\
\text { overall industrialization } \\
\text { and primary urbanization }\end{array}$ & $\begin{array}{l}\text { Realizing overall } \\
\text { industrialization, } \\
\text { urbanization and } \\
\text { modernization, being ranked } \\
\text { as moderately developed } \\
\text { country. Upgrading qualities } \\
\text { of economic products and } \\
\text { international distribution } \\
\text { rankings, improving the } \\
\text { percentages of knowledge } \\
\text { economy and modern service } \\
\text { industries, transnational } \\
\text { corporate becomes economic } \\
\text { entity. }\end{array}$ & \\
\hline $\begin{array}{l}\text { Management } \\
\text { Innovation }\end{array}$ & $\begin{array}{l}\text { Management innovation } \\
\text { of complete } \\
\text { marketization, } \\
\text { Standardization and } \\
\text { internationalization. } \\
\text { Overall implementation } \\
\text { of the strategy of } \\
\text { reinvigorating China } \\
\text { through human resource } \\
\text { development, upgrading } \\
\text { of human resource } \\
\text { development, from a } \\
\text { nation with large } \\
\text { population to a nation } \\
\text { with strong human } \\
\text { resources, the flow of } \\
\text { labors from turbulence to } \\
\text { stable, labor relations } \\
\text { become stable, achieving } \\
\text { transnational } \\
\text { management, reasonable } \\
\text { income distribution and } \\
\text { innovation. }\end{array}$ & $\begin{array}{l}\text { Management with Chinese } \\
\text { characteristics and HRM with } \\
\text { Chinese features become the } \\
\text { focus of attention, learning } \\
\text { organization, innovative } \\
\text { management, people } \\
\text { oriented management, } \\
\text { knowledge management, } \\
\text { culture management, cross } \\
\text { cultural management turn to } \\
\text { the focus of management } \\
\text { innovation, and work-life } \\
\text { balance is emphasized. }\end{array}$ & \\
\hline
\end{tabular}

Source: compilation by the author 


\section{Lin Xinqi \\ Theory of 25-year-cycle evolution - a hypothesis about the relationship between the transition of economic development mode and the human resource management innovation}

With economy development to a higher level, more and more emphasis is made on people orientation, work-life balance, focus of HRM innovation is to step into a harmonious, coordinated and culture management.In general, management innovation, particularly HRM innovation is from micro level to strategically higher level, from technological to more cultural level, to adapt to the model changes of economic development, to promote the model changes of economic development. This is a call of the era and a historical trend. Since the open-up policy three decades ago, China has turned to be a World Factory, an export-oriented manufacturing country, and a happy land for foreign and jointly invested enterprises. Nevertheless, no matter how fast the economy develops, there is an inevitable fact that the rules management, especially HRM adhere to are almost efficiency-prioritized, a traditional management principle and basic model, which had been proven efficient but inconsistent with the new trend of people orientation. It is gradually being changed and improved in the developed countries. In recent years, such heated topics as shortage in migrant workers, labor disputes, and calls for higher pay are not accidental but inevitable outcomes, which imply a new historical stage of social, economic and management development. This deserves great attention. By investigating and analyzing the economic development and trend in the future via 25-year-evolution perspective, we might have the following findings: for the three decades after the opening up policy or the over 60 years' development after the founding of new China, we have been searching for model of economic development and its changes, whereas the latter is firstly management innovation, particularly HRM innovation. More often than not, we need to call this management innovation management revolution.

\section{CONCLUSION}

As we can tell that for China, a nation with profound cultures and traditions, management innovation, particularly HRM innovation seems fairly difficult, urgent, and meaningful at the same time. Without management, especially HRM innovation, there is neither model change of economic development, nor achievements of reform and opening up, nor future development. If we take science, technology and modern management as wings of birds or wheels of cars, management innovation, particularly HRM innovation would be focus of China, whose science and technology is developing rapidly, whose economy is booming, it is the hope where future lies. Model changes of economic development call for management innovation, especially HRM innovation. Management innovation, particularly HRM innovation will promote the model changes of economic development, accelerate the implementation of scientific outlook on development, and promote scientific development of China.

\section{REFERENCES}

-Lin Xinqi, Paths and trends of the Changes of HRM in new China: Systems reforms and policies choices, Dalian: Dongbei University of Finance \& Economics Press, 2012.

- Lin Xinqi, Close connection between model changes of economic development and HRM innovation-scholar proposes "25-year-cycle Theory". Guang Ming Daily. 2011.5.18:15.(in Chinese)

-Knous, Structure and Change in Economic History. Shanghai: Shanghai Sanlian Book Store, Shanghai People's Press, 1994.

-Knous, Institutions, Institution Change and Economic Performance. Shanghai: Shanghai Sanlian Book Store, 1994.

-Schumpeter, Theory of Economic Development, the Commercial Press, 1990.

-Peter Drucker. Innovation and Entrepreneurship. Enterprise Management Press, 1989

-Prahalad, C. K., and Gary Hamel. "The Core Competence of the Corporation", Harvard Business Review, May June, 1990, pp. 79-91.

-Schatz \& Gutierrez-Rexach (2002).Conceptual Structure and Social Change: The Ideological Architecture of Democratization. Westport, CT: Praeger. 2002: 266

-Steward, Julian $\mathrm{H}$. The Theory of Cultural Change: The Methodology of Multilinear Evolution. University of Illinois Press, Urbana, 1955.

-Steward, Julian H. "The Concept and Method of Cultural Ecology." Readings in Anthropology, Vol. 2, pp.81-95. Ed. Crowell, New York, 1959.

-Steward, Julian H. Evolution and Ecology: Essays on Social Transformation. Eds. University of Illinois Press, Urbana, 1977. 